\title{
Scouring Pattern of Movable-Bed Channel Due to Mutual Constriction Structures: Laboratory-scale Model
}

\author{
Endro Prasetyo Wahono ${ }^{1}$, Ika Kustiani ${ }^{2}$, Suharno ${ }^{3}$ \\ Program Profesi Insinyur, Universitas Lampung \\ J1. Prof. Sumantri Brojonegoro No.1 Bandar Lampung 35145 \\ lepwahono@eng.unila.ac.id \\ ${ }^{2}$ ika.kustiani@eng.unila.ac.id \\ ${ }^{3}$ suharno_fisika@yahoo.co.id
}

Intisari - Pada beberapa tahun terakhir, permasalahan lingkungan telah menjadi hal yang sangat penting dalam proses pengambilan pada berbagai bidang rekayasa. Naturalisasi tumbuhanpada bantanran Sungai Ciliwung misalnya adalah salah satu contoh betapa aspek lingkungan telah diadopsi dalam manajemen sungai. Wahono (2002) menyatakan bahwa tumbuhan di bantaran sungai dapat mempunyai dampak yang analog dengan sebuah serial bangunan penyempitan. Untuk itu pengetahuan mengenai perilaku gerusan local akibat penyempitan berseri akan sangat penting untuk memahami resiko dari kerusakan bantaran dan bangunan sungai lain akibat gerusan local. Tujuan utama dari penelitian ini adalah untuk mengidentifikasi perilaku gerusan lokal akibat balok penyempitan berseri pada saluran terbuka dan lurus. Jarak antar balok dan lebar balok merupakan variabel bebas penelitian ini, sedangkan profil gerusan local merupakan salah satu variable tak bebas yang diteliti. Berdasarkan hasil analisa dari data penelitian, diperoleh tendensi bahwa dengan meningkatnya lebar balok penyempitan (dari $3 \mathrm{~cm}$ sampai $12 \mathrm{~cm}$ ) serta dengan meningkatnya jarak antar balok (dari 0,5b sampai 5b), menghasilakn kecenderungan penurunan luasan daerah gerusan lokal dan kecepatan alirannya. Gerusan lokal minimum (luasan) terjadi pada balok dengan lebar $12 \mathrm{~cm}$ dan atau pada jarak 5b. Sedangkan gerusan local maksimum (luasan) terjadi pada balok dengan lebar $3 \mathrm{~cm}$ dan atau jarak 0,5b. Penyempitan pada kedua sisi saluran serta saluran yang berkelok-kelok dengan aliran tidak tunak direkomendasikan sebagai seting penelitian lanjutan dari hasil ini untuk mendekati kondisi alami sungai dan memberikan penjelasan ilmiah naturalisasi bantaran sungai. Penelitian model fisik dengan skala yang yang mendekati ukuran alamiahnya sangat direkomendasikan untuk mendapatkan hasil yang lebih realistik.

Kata kunci — penyempitan berseri, gerusan dasar saluran, saluran terbuka lurus.

Abstract - In the recent years, environmental issue has been considered more significant in many aspect of engineering decision-making process. Re-introducing floodplain vegetations for example, have been proposed on the Ciliwung river-management projects. Wahono (2002) stated that vegetated floodplain system has similar physical effects as series of constriction structures. Therefore knowledge of scouring pattern affecting by series of constriction structures will be very important tool to understand the failure risk of riverbank and river structures. The main objective of this research is to identify scouring pattern due to series of constrictions blocks setting within a straight open channel. Distance between two constriction blocks and length of the constriction block were the independent variables of this research. Meanwhile, water profile, velocity profile and scouring depth profile along the channel were the dependent variables. Result of the research shows that the scouring area and their corresponding velocities tends to decrease by increasing constriction length (from $3 \mathrm{~cm}$ to $12 \mathrm{~cm}$ ) as well as constriction distance (from $0,5 \mathrm{~b} \mathbf{~ c m}$ to $5 \mathrm{~b}$ ). Minimum changes on local scour occur for block length of $12 \mathrm{~cm}$ and block distance of $5 \mathrm{~b}$. Meanwhile the maximum scour occurs for block length of $3 \mathrm{~cm}$ and block distance of $0,5 \mathrm{~b}$. Model of both-side constriction with unsteady flow is recommended for further research to have better overview on effects of the floodplainnaturalization. The similar experiment with better scale is strongly recommended. Result of the research is an important start on studying correlation between morphodynamic of riverbed and vegetated floodplain.

Keywords - mutual constriction, local scouring, straight open channel. 


\section{INTRODUCTION}

In the recent years, environmental issue has been considered more significant in many aspect of engineering decision-making process. Re-introducing floodplain vegetations for example, have been proposed on the Ciliwung river-management projects. The phenomena has also been studied in order to enhance understanding on uncertainty behaviour of the natural river. In studying floodplain hydraulics, such vegetated-floodplain reach behaves as a constriction. In addition to that, Wahono (2002) stated that vegetated floodplain system has similar physical affects as series of constriction structures. Therefore knowledge of scouring pattern affecting by series of constriction structures will be very important tool to understand the failure risk of riverbank and other river structures.

Past researches were conducted by Wahono (2002) and, previously, by Rath (2001) regarding the principle of mutual constrictions within the river channel using both analytical and numerical approach. It will be better to combine such study with analytical, numerical and scale model as a comprehension approach. In addition to that, Wahono (2004) stated that there is unique hydraulic effect due to constriction density. Therefore, this research will be a basic start for the more complicated and sophisticated physical model regarding river management.

Based on Rath (2001), changes on floodplain's dimension can be considered as a constriction in term of hydraulic point of view. This statement supported by Wahono (2002), who studied effect of vegetation pattern within floodplain. Wahono (2002) concluded that basically vegetation bars acting as constriction blocks and initiates changes on flow pattern. In addition to that, Imamoto et al (1993) indicated that within a straight channel, secondary flow has to be taken into account on hydraulic analysis of open channel flow. For the latest scale model experiment, Liriano, et al. (2001) conducted observation on curved fixed-bed model, and single block of solid material was placed in different location within the floodplain. They concluded that in certain location of obstruction block was more pronounce affecting the system compare to others location. The latest research was done by Wahono (2004), who studied hydraulic effect due to mutual constriction on fixed-bed channel. It is concluded that constriction density have a significant effect on water and velocity profile. Therefore it will be a significant knowledge if those phenomena can be applied on the movable-bed physical model, which is closer to the field condition.

Study regarding series of constriction structures is still quite rare compare to study on single constriction. Meanwhile, in nature, particularly in river management, most of them occur as series of constriction structures Therefore, study concerning scouring pattern due to series of constriction structures will be a great challenge.

Research regarding single constriction within open channel is more or less already well developed. However, effects of mutual constrictions have not been understood clearly. Rath (2001), studied effect of mutual changes of floodplain width, followed by Wahono (2002) who studied behaviour of riverbed wave due to mutual vegetated reaches within the floodplain. Both researcher were work on analytical and numerical aspect, meanwhile scale model of this phenomenon has not been studied yet. Therefore, this research will be very important start to learn the phenomenon on the scale model point of view.

The main objective of this research is to identify scouring pattern due to series of constrictions blocks setting within a straight open channel. Distance between two constriction blocks and length of the constriction block are the independent variables of this research. Meanwhile, water profile, velocity profile and scouring depth profile along the channel are the dependent variables. Result of the research will be an important knowledge on hydraulics and morphodynamic of riverbed with vegetated floodplain, risk probability of designing river structures as well as river management in broader view

Flow in a channel with a mobile bed is usually accompanied by a transport of sediments; erosion and deposition might be 
the consequence. Additional erosion of sediment will be caused, where there is a local change in the geometry of the channel or in the flow.

Different kind of local scouring is encountered in fluvial hydraulics. Constriction scour will be occurred if the width of the channel is reduced. The similar phenomenon will also be encountered due to change of floodplain roughness.

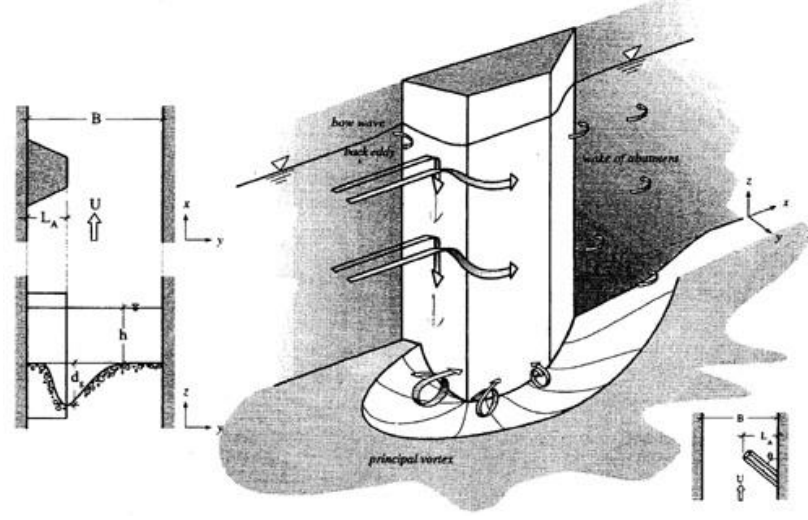

Fig 1. Scheme of flow pattern and local scour around an abutment

\section{RESEARCH METHOD}

The main activities of this research will be laboratory works to study scouring pattern due to series of constriction structures setting within a straight open channel. Method of the research will be movable-bed physical modelling on tilting flume available at the hydraulic laboratory UNILA. Steady and sub-critical flow will be adjusted trough out the experiments. Distance between two constriction blocks, length of the constriction block and discharge will be set as the independent variables. Meanwhile, water profile, velocity profile and scouring depth pattern along the channel, as effects of the constriction series, will be measures as the dependent variables.

1. Three different lengths of constriction block (b) will be used: $12 \mathrm{~cm}, 6 \mathrm{~cm}$, and 3 $\mathrm{cm}$. Three difference settings of blocks distance $(0.5 b, 2 b$ and $5 b)$ will be conducted to know effect of the block density.

2. Water depth measurement using point gauges will be conducted to perform water profile on each experiment.
3. Velocity profiles measurement on every important point will be conducted to study changes of velocity profile due to the mutual constrictions.

4. Scouring depth measurement using point gauges and camera will be conducted to perform scouring depth profile on each experiment.

5. Analysis of the results will discuss on how important density of the constriction block affect water profile, velocity profile and scouring pattern of the system

In order to have a better and focus results, this result will only discussess topic related to the following aspects:

1. Changes on velocity profile as well as water surface profile due to three types of constriction blocks.

2. Changes on scouring pattern as well as water surface profile due to three types of distances between two constriction blocks.

Constriction blocks were installed within the tilting flume in mutual sequences. Three different distance between blocks were installed for every different block's dimension. First block were put in the distance of one meter from the upper control section (reservoir chamber). Series of the blocks were installed for $2,5 \mathrm{~m}$ long. Those three different distance used in this experiment are: $0,5 b ; 2 b$ and $5 b$.

After preparing and installing the corresponding block for every different dimension and distance of the block system, pump was turned on to discharge tilting flume with the same discharge as installed for flume without blocks.

Velocity data measured using propeller type of current meter. Ideally, the velocity is taken using pitot meter in order to ovoid any disturbances. Since the pitot meter in not available, the current-meter is chosen for measuring velocity. Velocity measurement conducted on the every important point which considered can represent the system condition particularly on location where velocity predicted to be prominently changes. Velocity changes due to the mutual constrictions are then observed.

Meanwhile scouring depth and water level profile is measured using point gauges. The equipments were installed on the upstream 
control point, downstream control point and every important point along the system.

Steps as explained above were repeated for every different block dimension and distance. Results of every measurement series is then analysed to have an idea the effect of block density and block dimension to changes of the velocity and water level profile. Result of the measurement data will be presented as graph represents water level changes on distance basis, as well as velocity pattern along the distance.

Comparison among the different system is the conducted to have a more detail result. From the analysis it is assumed that effect of the mutual constriction can be drawn as compared with the single constriction phenomena

\section{RESULT AND DISCUSSION}

Generally, scouring pattern is driven by velocity changes near the block due to reducing of flow area. The phenomena also occur on this research since the flow area reduced by setting different type of blocks.

Following are result of the research presented on top view aas well as side view of the scouring pattern after two hours running.
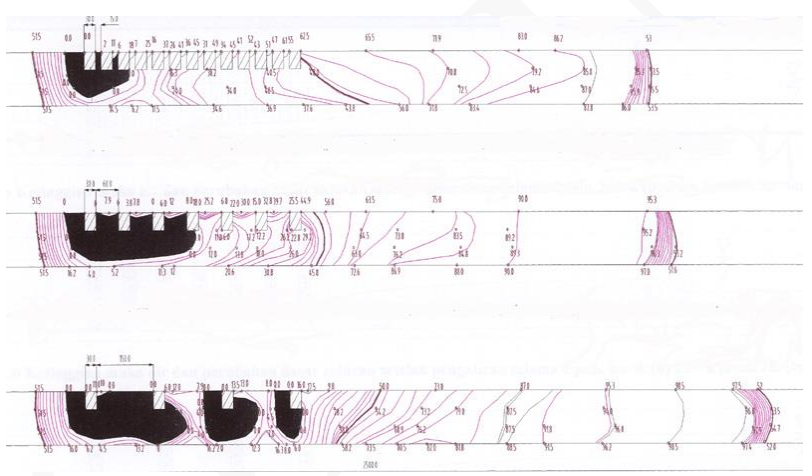

Fig 2. Topview of scouring pattern of $3 \mathrm{~cm}$ for 3 different block distances

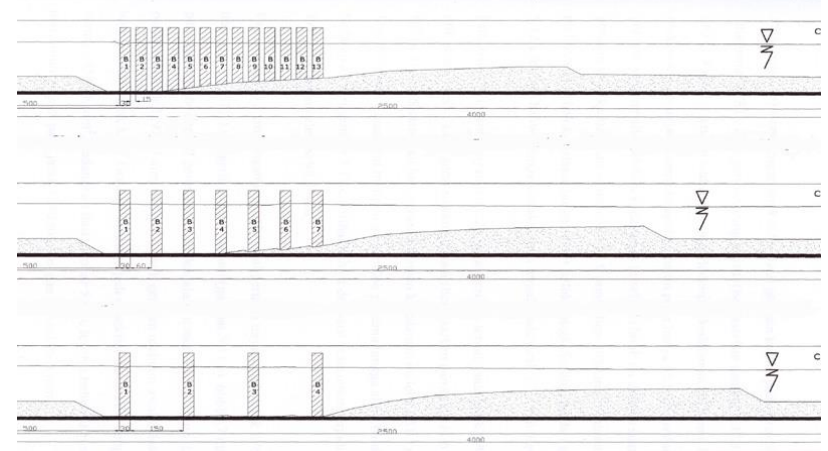

Fig 3. Side view of scouring pattern of $3 \mathrm{~cm}$ for 3 different block distances

\section{CONCLUSION}

Based on the analysis of the research result conclusion can be drawn as the following:

1. By increasing constriction length (from 3 $\mathrm{cm}$ to $12 \mathrm{~cm}$ ), the scouring areas also increase. Maximum changes on relative local scouring depth occur for block length of $3 \mathrm{~cm}$.

2. By increasing constriction distance (from $0,5 \mathrm{~b} \mathrm{~cm}$ to $5 \mathrm{~b}$ ), the scouring areas also increase. Maximum changes on water level relative occur for block distance of $5 b$.

3. Due to the mutual constriction, maximum changes of the water level occur on the first constriction block and getting closer to the basic level to the downstream direction.

4. By reducing length of the constriction block, the correspond velocity within the constriction part increase. Maximum velocity occurs for the constriction length of $3 \mathrm{~cm}$.

5. Velocity within the constriction block increase as distance of the sequence constriction decrease. Maximum changes on velocity occur for the distance of $0,5 \mathrm{~b}$.

6. As the minimum changes is concerned, standard deviation of the changes is used. The smallest standard deviation, in term of water level and velocity, resulted by constriction block of $6 \mathrm{~cm}$ with distance of $0,5 b$.

7. General pattern of changes on water level and velocity as the following:

a. At the front face of the constriction, water level increase meanwhile velocity decrease. 
b. In the part of the constriction zone (1/3 from front point) water level increase as velocity decrease.

For more practical result, further advance research is required. Unsteady flow boundary during the experiments is recommended to be conducted in order to have more practical result and related to the river management problems. Both side constriction as well as meandering channel also recommended to include in the further result to be close to the river actual problem and giving overview of the floodplain-naturalization. The similar experiment with better scale is strongly recommended as the basic for the further advance research

\section{ACKNOWLEDGMENTS}

We would like to express our appreciation to UPTD BPSDA Seputih-Sekampung for providing us the hydrological data. Authors would also like to thank all faculty member of Professional Engineer Department, University of Lampung for their support given to accomplish this paper.

\section{REFERENCES}

[1] Imamoto, H., Ishigaki, T., Shiono, K. Secondary Flow in a Straight Open Channel. Kyoto University. Jepang. 1993.

[2] Knight, D.W., K. Shiono. River Channel and Floodplain Hydraulics. Floodplain Processes. John Wiley \& Sons Ltd. Chichester, pp. 139-181. New York. 1996.

[3] Lejeune, A. Applied Hydraulics A. IHE Delft-The Netherlands. Belanda. 1994.

[4] Liriano, S.L., Marriot, M.J., Day, R.A. Experimental Observation of Obstruction on Floodplain. University of Hertfordshire. 2001.

[5] Raju, K.G. Aliran Melalui Saluran Terbuka. Penerbit Erlangga. Jakarta. 1986.

[6] Rath, S. River Morphological Changes Induced by Spatial Variations in Floodplain Dimensions. Hamburg University of Technology. Jerman. 2001.

[7] Triatmodjo, Bambang. (a). Hidrolika I. Beta Offset. Yogyakarta. 1995.

[8] Triatmodjo, Bambang. (b). Hidrolika II. Beta Offset. Yogyakarta. 1995.

[9] Wahono, E.P. Behaviour of Riverbed Disturbances due to Floodplain ReNaturalisation and Discharge Variation. IHE Delft-The Netherlands. Belanda. 2002. 